\title{
Pengaruh Ekstrak Etanol Propolis Terhadap Aktivitas dan Kapasitas Fagositosis pada Kultur Makrofag yang Diinfeksi Enteropathogenic Escherichia coli (EPEC)
}

\author{
Iis Herawati, ${ }^{1}$ Usep A. Husin, ${ }^{2}$ Sunarjati Sudigdoadi ${ }^{2}$ \\ ${ }^{1}$ Program Studi Analis Kesehatan Sekolah Tinggi Kesehatan Jendral A. Yani Cimahi, \\ ${ }^{2}$ Departemen Mikrobiologi dan Parasitologi Fakultas Kedokteran Universitas Padjadjaran Bandung
}

\begin{abstract}
Abstrak
Penanganan penyakit infeksi diperlukan suatu imunostimulator. Propolis adalah campuran resin yang dikumpulkan lebah dari tumbuh-tumbuhan, digunakan sebagai material isolasi sarang lebah, merupakan bahan yang berpotensi sebagai imunostimulator. Penelitian dilakukan di Laboratorium Penelitian dan Pengujian Terpadu Universitas Gadjah Mada pada Januari-Maret 2013. Penelitian ini bertujuan menganalisis peningkatan aktivitas dan kapasitas fagositosis kultur makrofag yang diberi ekstrak etanol propolis terhadap Enteropathogenic Escherichia coli (EPEC). Desain penelitian eskperimen. Ke dalam kultur makrofag yang diperoleh dari tiga orang subjek, masing-masing diberi ekstrak etanol propolis 6,25; 12,5; 25; 50, dan $100 \mu \mathrm{g} / \mathrm{mL}$ serta kontrol tanpa ekstrak etanol propolis. Inkubasi dilakukan satu hari. Kultur diinfeksikan EPEC selama 30 menit, diwarnai dengan Giemsa dan diamati dengan mikroskop. Persentase aktivitas fagositosis diperoleh dengan menghitung jumlah makrofag yang aktif dalam 100 makrofag. Nilai kapasitas fagositosis diperoleh dengan menghitung jumlah bakteri yang difagosit oleh 50 makrofag. Uji analysis of variance (ANOVA) menunjukkan perbedaan signifikan aktivitas maupun kapasitas fagositosis kultur makrofag yang diberi ekstrak etanol propolis dibanding dengan kontrol $(\mathrm{p}=0,000)$. Uji Tukey HSD pada aktivitas fagositosis menunjukkan hasil signifikan antara kontrol dan konsentrasi $6,25 \mu \mathrm{g} / \mathrm{mL}(\mathrm{p}=0,008)$, sedangkan pada kapasitas fagositosis terlihat antara kontrol dan konsentrasi $12,5 \mu \mathrm{g} / \mathrm{mL}$ $(\mathrm{p}=0,001)$. Simpulan, ekstrak etanol propolis meningkatkan aktivitas dan kapasitas fagositosis kultur makrofag terhadap EPEC dengan konsentrasi minimum 12,5 g/mL. [MKB. 2015;47(2):102-8]
\end{abstract}

Kata kunci: Aktivitas fagositosis, Enteropathogenic Escherichia coli (EPEC), kapasitas fagositosis, makrofag, propolis

\section{Effect of Ethanolic Extract Propolis on Phagocytosis Activity and Capacity in Macrophages Culture Infected by Enteropathogenic Escherichia coli (EPEC)}

\begin{abstract}
The use of immunostimulant for infectious diseases treatment is needed. Propolis is a mixture of resin collected from plants by bees and used as an insulating material in beehives which has a potential as immunostimulant. This study was performed at Laboratory of Research and Integrated Testing, Gadjah Mada University, in JanuaryMarch 2013. This experimental research aimed to analyze the increase of phagocytosis activity and capacity on macrophages culture added by propolis ethanolic extract against Enteropathogenic Escherichia coli (EPEC). The design of this study was experimental study. Macrophage cultures obtained from three subjects were individually culture supplemented with the $6.25,12.5,25,50$, and $100 \mu \mathrm{g} / \mathrm{mL}$ propolis ethanolic extract. A control without the addition of propolis ethanolic extract is also used. Cultures were incubated for one day. Macrophage cultures were infected by EPEC for 30 minutes, stained by Giemsa, and observed by microscope. Percentage of phagocytosis activity is determined by the number of active macrophages per 100 macrophages. The phagocytosis capacity value was determined by counting the number of bacteria that were phagocytized by 50 macrophages. Analysis of variance (ANOVA) showed a significantly different phagocytosis activity and capacity between macrophage cultures added by propolis ethanolic extract and control $(\mathrm{p}=0.000)$. Tukey HSD analysis showed significantly different phagocytosis activity between control and subject with a concentration of $6.25 \mu \mathrm{g} / \mathrm{mL}(\mathrm{p}=0.008)$ whereas the difference in phagocytosis capacity was seen between control and subject with a concentration of $12.5 \mu \mathrm{g} / \mathrm{mL}(\mathrm{p}=0.001)$. In conclusion, propolis ethanolic extract is able to increase the phagocytosis activity and capacity of macrophages against EPEC with a minimum concentration of $12.5 \mu \mathrm{g} / \mathrm{mL}$. [MKB. 2015;47(2):102-8]
\end{abstract}

Key words: Enteropathogenic Escherichia coli (EPEC), macrophage, phagocytosis activity, phagocytosiscapacity, propolis

Korespondensi: Iis Herawati, S.Pd, M.Kes, Program Studi Analis Kesehatan STIKES Jenderal Ahmad Yani, Jalan Terusan Jenderal Sudirman Cimahi, mobile 085223015407, e-mail: iis.herawati73@yahoo.com 


\section{Pendahuluan}

Penyakit infeksi merupakan masalah yang global dan memerlukan penanganan komprehensif. Selain pengobatan dengan antibiotik, pemakaian obat yang dapat meningkatkan daya tahan tubuh perlu dipikirkan. ${ }^{1}$ Salah satu jenis bahan yang memiliki potensi sebagai imunostimulator alami yaitu propolis. Propolis adalah suatu zat yang dihasilkan oleh lebah madu karena bahannya lengket seperti lem disebut sebagai bee glue. Propolis dihasilkan lebah yaitu dengan cara mengumpulkan resin atau getah dari berbagai macam tumbuhan, kemudian resin ini bercampur dengan saliva dan berbagai enzim yang ada pada lebah. Bagi lebah sendiri propolis bersifat desinfektan (antimikrob) yang dapat membunuh bakteri ataupun virus yang masuk ke sarangnya. ${ }^{2}$

Propolis mengandung senyawa kompleks vitamin, mineral, enzim, serta senyawa fenolik dan flavonoid. ${ }^{3}$ Flavonoid termasuk di dalam kelompok senyawa alamiah dengan struktur fenol yang bervariasi dan dapat ditemukan dalam buah, sayuran, kacang-kacangan, dan produk herbal. ${ }^{4}$ Flavonoid mempunyai berbagai efek farmakologis antara lain sebagai imunostimulan, antikanker, antioksidan, antiviral, antialergi, dan antihepatotoksik. ${ }^{5,6}$ Selain itu, caffeic acid phenetyl esther (CAPE) yang memiliki aktivitas dalam hal meningkatkan respons imun juga terkandung di dalamnya. ${ }^{7}$

Penelitian-penelitian sebelumnya mengenai peran imunostimulator propolis sudah banyak dilakukan. Telah diungkapkan bahwa pemberian ekstrak etanol propolis dengan kadar sebesar 200 $\mathrm{mg} / \mathrm{kg}$ pada tikus selama 3 hari berturut-turut dapat meningkatkan ekspresi toll like receptor-2 (TLR-2) dan TLR-4. ${ }^{8}$ Makrofag dapat diaktifkan oleh TLR. Makrofag mempunyai peranan yang sangat penting yaitu sebagai fagosit pada sistem imun innate dan sebagai antigen presenting cells (APC) yang mengawali respons imun adaptif. TLR dapat mengaktifkan respons imun innate dan merangsang produksi berbagai protein yang berperan dalam fungsi penting makrofag. TLR2 yang dapat mengenal keberadaan lipoprotein pada bakteri gram positif, sedangkan TLR-4 dapat mengenal keberadaan lipopolisakarida pada bakteri gram negatif. ${ }^{9-11}$

Enteropathogenic Escherichia coli adalah bakteri gram negatif batang yang merupakan penyebab penting kasus diare pada anak dinegara berkembang. ${ }^{12}$ Pencegahan penyakit ini dapat dilakukan dengan memberikan imunostimulator untuk meningkatkan respons imun. Penelitian ini dilakukan dengan tujuan melihat potensi propolis dalam meningkatkan respons imun innate melalui pemeriksaan aktivitas dan juga kapasitas fagositosis kultur makrofag terhadap EPEC. Hasil penelitian ini diharapkan mampu memberikan informasi manfaat propolis sebagai imunostimulator untuk pencegahan terhadap penyakit infeksi oleh bakteri khususnya EPEC.

\section{Metode}

Penelitian dilaksanakan pada bulan JanuariMaret 2013. Proses ekstraksi propolis dilakukan di Laboratorium Bahan Alam Fakultas Farmasi Institut Teknologi Bandung. Isolasi kultur makrofag dan uji fagositosis dilaksanakan di Lembaga Penelitian dan Pengujian Terpadu Universitas Gadjah Mada (LPPT-UGM). Penelitian dilakukan dengan desain eksperimen.

Propolis Afis mellifera diperoleh dari peternak lebah di daerah Malang. Ekstrak diperoleh dengan melarutkan propolis dengan etanol 95\% perbandingan 1:10, diputar dengan termostirer berkecepatan $150 \mathrm{rpm}$. Filtrat yang diperoleh disaring dan diuapkan dengan rotary evaporator pada suhu $70^{\circ} \mathrm{C}$. Ekstrak diencerkan dengan dimethyl sulfoxide (DMSO) sehingga konsentrasi propolis dalam setiap microtube berturut-turut $200 \mu \mathrm{g} / \mathrm{mL}, 100 \mu \mathrm{g} / \mathrm{mL}, 50 \mu \mathrm{g} / \mathrm{mL}, 25 \mu \mathrm{g} / \mathrm{mL}$, 12,5 , dan $6,25 \mu \mathrm{g} / \mathrm{mL}^{13}$

Untuk pembuatan kultur makrofag, tiga orang darah subjek diambil secara aseptik dari vena mediana kubiti dan ditampung di dalam tabung berisi antikoagulan heparin. Komponen leukosit dipisahkan dengan sentrifus kecepatan $1.500 \mathrm{rpm}$ selama 15 menit sehingga terbentuk 3 lapisan yaitu komponen eritrosit, buffy coat yang mengandung leukosit, dan plasma. Buffy coat dipisahkan dan dipindahkan ke dalam falcon tube, ditambah hank's balanced salt solution (HBSS) (1:1), dikocok. Campuran buffy coat dan HBSS ditambahkan ke dalam falcon tube yang berisi histopaque (1:1), selanjutnya disentrifus dengan kecepatan $1.500 \mathrm{rpm}$ selama 30 menit. Peripheral blood mononuclear cell (PBMC) yang diperoleh dipipet dan dipindahkan ke dalam falcon tube dan dicuci dengan HBSS (1:1).

Dua ratus mikroliter suspensi PBMC dari setiap subjek, masing-masing dimasukkan ke dalam sumuran (multidish 24 well) dengan dasar diletakkan coverslip, kemudian diinkubasi selama 120 menit pada $37^{\circ} \mathrm{C}$ dan $5 \% \mathrm{CO}_{2}$. Supernatan pada setiap sumuran dibuang, dicuci dengan HBSS, dan ditambahkan $500 \mu \mathrm{L}$ medium Roswell Park Memorial Institute (RPMI) lengkap, 
inkubasi dilanjutkan selama $7-10$ hari pada $37^{\circ} \mathrm{C}$ dan $5 \% \mathrm{CO}_{2}$. Untuk melihat maturasi sel monosit menjadi makrofag dapat dilakukan dengan melihat karakteristik sel di bawah mikroskop inversi. ${ }^{14}$

Bakteri uji yang dipergunakan yaitu EPEC dengan kekeruhan 0,5 McFarland. Ke dalam tabung reaksi steril dimasukkan $5 \mathrm{~mL}$ phosphat buffer saline (PBS). Dengan mengunakan ose steril dimasukkan masing-masing koloni bakteri dari agar nutrien miring ke dalam tabung yang telah berisi PBS. Kekeruhan suspensi bakteri diukur menggunakan nephelometer McFarland sehingga didapat suspensi dengan kekeruhan 0,5 McFarland (setara dengan $150 \times 10^{6} / \mathrm{mL}$ ). ${ }^{15}$

Untuk pengujian aktivitas fagositosis, pada sumuran perlakuan yang berisi sel makrofag dimasukkan masing-masing $500 \mu \mathrm{L}$ variasi ekstrak etanol propolis dan medium RPMI sehingga konsentrasi akhir propolis pada setiap sumuran adalah $100 \mu \mathrm{g} / \mathrm{mL}, 50 \mu \mathrm{g} / \mathrm{mL}, 25 \mu \mathrm{g} /$ $\mathrm{mL}, 12,5 \mu \mathrm{g} / \mathrm{mL}, 6,25 \mu \mathrm{g} / \mathrm{mL}$, dan kontrol tanpa propolis. Plate sumuran digoyangkan secara merata dan diinkubasi selama 1 hari sehingga terjadi interaksi antara propolis dan makrofag. Kultur medium pada seluruh sumuran dibuang, dicuci, dan diisi lagi dengan $500 \mu \mathrm{L}$ PBS. Ke dalam kultur makrofag kontrol dan perlakuan pada masing-masing individu dimasukkan bakteri EPEC dan dibiarkan selama 30 menit. Semua sel pada setiap sumuran dicuci dengan PBS sebanyak 2 kali. Selanjutnya, sel difiksasi dengan metanol absolut selama 1 menit dan diwarnai dengan Giemsa selama 10 menit, kemudian dibilas dengan air mengalir. Coverslip pada seluruh sumuran lalu diangkat dan dikeringkan, dilihat di bawah mikroskop mempergunakan minyak imersi dengan perbesaran objektif 100x. Aktivitas fagositosis ditetapkan berdasarkan jumlah sel makrofag yang aktif melakukan proses fagositosis dalam 100 sel fagosit. ${ }^{16}$

Data yang diperoleh dari pengujian aktivitas dan kapasitas fagositosis pada kultur tiap individu dilakukan uji normalitas, kemudian perbedaan aktivitas dan kapasitas fagositosis pada kelompok kontrol dan perlakuan dianalisis dengan uji analysis of variance (ANOVA) pada taraf nyata $5 \%$ dan untuk melihat perbedaan antarkelompok perlakuan dilanjutkan dengan uji Tukey honestly significant difference (HSD).

\section{Hasil}

Pengujian aktivitas dan kapasitas fagositosis sel makrofag terhadap EPEC dapat dilihat pada
Tabel 1. Pada ketiga subjek penelitian terlihat bahwa nilai aktivitas dan kapasitas fagositosis terendah terdapat pada sel makrofag yang tidak diberi ekstrak etanol propolis (kontrol). Nilai aktivitas dan kapasitas tertinggi terdapat pada sel makrofag yang diberi ekstrak etanol $100 \mu \mathrm{g} /$ $\mathrm{mL}$.

Hasil uji one way ANOVA didapatkan bahwa keseluruhan kelompok pada variabel aktivitas fagositosis makrofag memiliki perbedaan yang bermakna secara statistik dibanding dengan kontrol $(p=0,000)$. Pemberian ekstrak etanol propolis terhadap aktivitas fagositosis makrofag pada kultur semua subjek penelitian mempunyai pengaruh yang sama, semakin besar konsentrasi maka aktivitasnya semakin tinggi, seperti terlihat pada Gambar 2.

Seperti halnya aktivitas fagositosis, pada uji one way ANOVA kapasitas fagositosis makrofag juga menunjukkan perbedaan yang bermakna secara statistik antara kontrol dengan perlakuan $(\mathrm{p}=0,000)$. Grafik hasil pemeriksaan kapasitas fagositosis dapat dilihat pada Gambar 3. Untuk dapat melihat perbedaan pengaruh konsentrasi terhadap aktivitas dan juga kapasitas fagositosis antara masing-masing perlakuan yang dilakukan dengan uji Tukey HSD dengan taraf nyata 5\% seperti terlihat pada Tabel 2 .

\section{Pembahasan}

Pada penelitian ini, kultur makrofag berasal dari tiga subjek penelitian yang berbeda yang masing-masing diberikan ekstrak etanol dengan

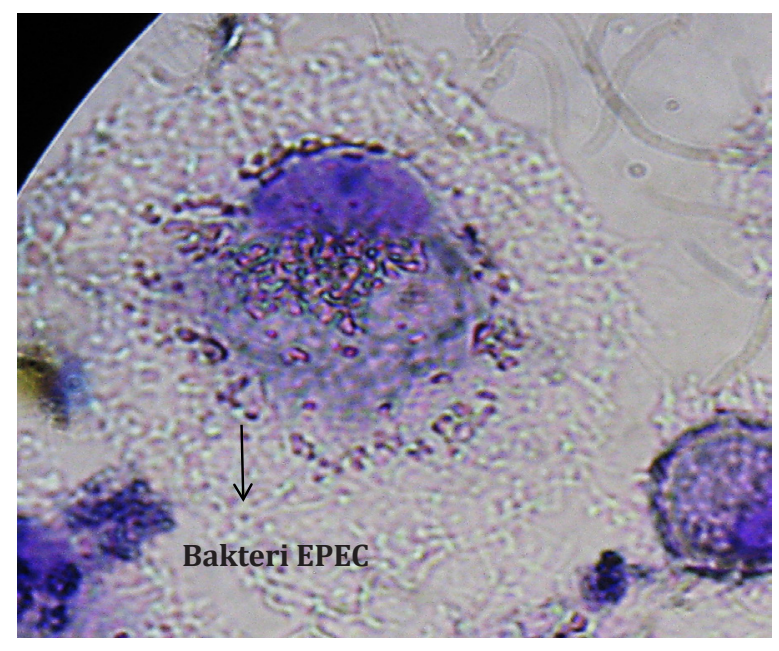

Gambar 1 Fagositosis EPEC oleh Makrofag Dilihat dengan Mikroskop Cahaya Perbesaran 1.000x 
Tabel 1 Aktivitas dan Kapasitas Fagositosis Makrofag pada Tiga Subjek Penelitian

\begin{tabular}{|c|c|c|c|c|c|}
\hline \multirow[t]{2}{*}{ No. Subjek } & \multirow{2}{*}{$\begin{array}{c}\text { Konsentrasi } \\
\text { Propolis }(\mu \mathrm{g} / \mathrm{mL})\end{array}$} & \multicolumn{2}{|c|}{ Aktivitas Fagositosis } & \multicolumn{2}{|c|}{ Kapasitas Fagositosis } \\
\hline & & Rata-rata & $95 \%$ IK & Rata-rata & $95 \%$ IK \\
\hline \multirow[t]{6}{*}{1} & 0 & 53 & $50,31-54,69$ & 1244 & $1.125,45-1.361,55$ \\
\hline & 6,25 & 60 & $57,31-61,69$ & 1429 & $1.311 .20-1547,30$ \\
\hline & 12,5 & 60 & $58,06-62,44$ & 1474 & $1.356 .20-1.592 .30$ \\
\hline & 25 & 71 & $68,81-73,19$ & 1501 & $1.382,45-1.618,55$ \\
\hline & 50 & 80 & $78,06-82,44$ & 1660 & $1.541,45-1.777,55$ \\
\hline & 100 & 82 & $79,81-84,19$ & 1674 & $1.555,70-1.791,80$ \\
\hline \multirow[t]{6}{*}{2} & 0 & 61 & $58,56-62,94$ & 1272 & $1.153,70-1.389,80$ \\
\hline & 6,25 & 62 & $59,81-64,19$ & 1352 & $1.233,70-1.469,80$ \\
\hline & 12,5 & 65 & $62,31-66,69$ & 1575 & $1.456,70-1.692,80$ \\
\hline & 25 & 79 & $77,06-81,44$ & 1643 & $1.524,95-1.761,05$ \\
\hline & 50 & 84 & $81,81-86,19$ & 1677 & $1.559,20-1.795,30$ \\
\hline & 100 & 89 & $87,06-91,44$ & 1733 & $1.614,45-1.850,55$ \\
\hline \multirow[t]{6}{*}{3} & 0 & 61 & $59,06-63,44$ & 1338 & $1.220,20-1.456,30$ \\
\hline & 6,25 & 63 & $60,56-64,94$ & 1316 & $1.197,95-1.434,05$ \\
\hline & 12,5 & 66 & $64,06-68,44$ & 1429 & $1.311,20-1.547,30$ \\
\hline & 25 & 71 & $69,06-73,44$ & 1693 & $1.574,951.811,05$ \\
\hline & 50 & 80 & $77,81-82,19$ & 1754 & $1.635,45-1.871,55$ \\
\hline & 100 & 84 & $81,81-86,19$ & 1751 & $1.632,70-1.868,80$ \\
\hline
\end{tabular}

konsentrasi 6,$25 ; 12,5 ; 25 ; 50$; dan $100 \mu \mathrm{g} / \mathrm{L}$ serta kontrol yang tidak diberikan ekstrak etanol propolis. Analisis grafik untuk aktivitas fagositosis menunjukkan hubungan kenaikan konsentrasi ekstrak etanol propolis dengan nilai aktivitas fagositosis. Semakin tinggi konsentrasi maka semakin naik pula kemampuan aktivitas makrofag untuk memfagositosis EPEC. Analisis statistik dengan ANOVA juga menunjukkan bahwa hipotesis diterima, pemberian propolis secara umum mampu meningkatkan secara nyata aktivitas fagositosis makrofag serta

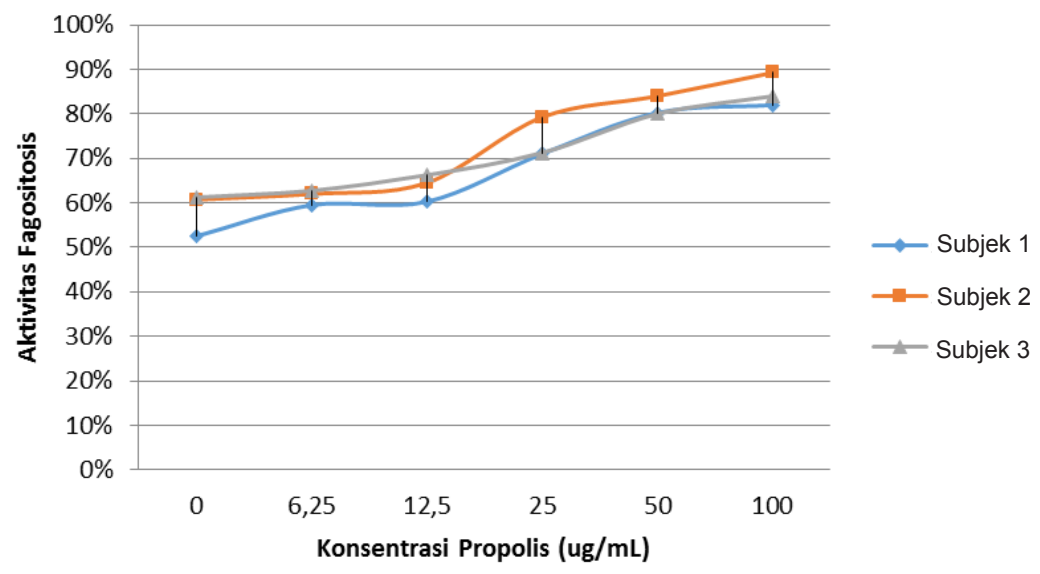

Gambar 2 Grafik Hasil Pemeriksaan Aktivitas Fagositosis pada Tiga Subjek Penelitian 


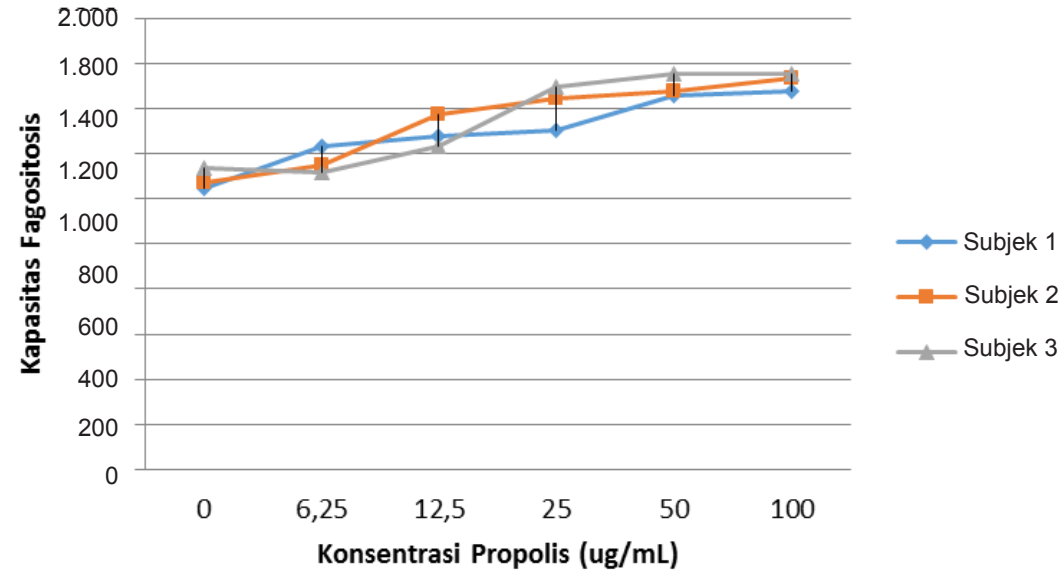

Gambar 3 Grafik Hasil Pemeriksaan Kapasitas Fagositosis pada Tiga Subjek Penelitian

peningkatannya dapat dipengaruhi karena ada perbedaan konsentrasi propolis.

Analisis grafik untuk kapasitas fagositosis menunjukkan kenaikan nilai kapasitas fagositosis antara kontrol dan perlakuan, tetapi pada konsentrasi $>25 \mu \mathrm{g} / \mathrm{mL}$ peningkatannya tidak terlalu signifikan dan grafik terlihat mendatar. Hal ini terjadi kemungkinan karena sel makrofag telah mencapai kapasitas maksimalnya. Hasil penelitian menunjukkan bahwa semakin tinggi konsentrasi ekstrak etanol propolis maka semakin tinggi pula aktivitas fagositosisnya, sedangkan pada kapasitas fagositosis terlihat bahwa pemberian ekstrak etanol pada konsentrasi 50 dan $100 \mu \mathrm{g} / \mathrm{mL}$ kenaikannya tidak terlalu signifikan Hal ini kemungkinan terjadi karena kapasitas fagositosis makrofag telah mencapai batas maksimal.

Berdasar analisis antarperlakuan diketahui bahwa konsentrasi minimal ekstrak etanol

Tabel 2 Hasil Uji Tukey HSD Antarperlakuan

\begin{tabular}{|c|c|c|c|}
\hline \multicolumn{2}{|c|}{ Konsentrasi $(\mu \mathrm{g} / \mathrm{mL})$} & \multirow{2}{*}{$\begin{array}{c}\text { Nilai p Aktivitas } \\
0,008^{*}\end{array}$} & \multirow{2}{*}{$\frac{\text { Nilai p Kapasitas }}{0,545}$} \\
\hline 0.00 & 6,25 & & \\
\hline & 12,50 & $0,000^{*}$ & $0,001^{*}$ \\
\hline & 25,00 & $0,000^{*}$ & $0,000^{*}$ \\
\hline & 50,00 & $0,000^{*}$ & $0,000^{*}$ \\
\hline & 100,00 & $0,000^{*}$ & $0,000^{*}$ \\
\hline \multirow[t]{4}{*}{6.25} & 12,50 & 0,136 & 0,104 \\
\hline & 25,00 & $0,000^{*}$ & $0,000^{*}$ \\
\hline & 50,00 & $0,000^{*}$ & $0,000^{*}$ \\
\hline & 100,00 & $0,000^{*}$ & $0,000^{*}$ \\
\hline \multirow[t]{3}{*}{12.50} & 25,00 & $0,000^{*}$ & 0,147 \\
\hline & 50,00 & $0,000^{*}$ & $0,001^{*}$ \\
\hline & 100,00 & $0,000^{*}$ & $0,000^{*}$ \\
\hline \multirow[t]{2}{*}{25.00} & 50,00 & $0,000^{*}$ & 0,500 \\
\hline & 100,00 & $0,000^{*}$ & 0,245 \\
\hline 50.00 & 100,00 & $0,002^{*}$ & 0,997 \\
\hline
\end{tabular}

Keterangan: angka yang diikuti tanda * menunjukkan perbedaan yang nyata di antara konsentrasi propolis 
propolis yang meningkatkan signifikan baik aktivitas maupun kapasitas fagositosis adalah $12,5 \mu \mathrm{g} / \mathrm{mL}$. Pada penelitian ini pengujian dilakukan dengan cara in vitro sehingga molekulmolekul yang terkandung dalam propolis dapat langsung berinteraksi dengan reseptor pada sel. Pada pengujian in vivo kemungkinan konsentrasi yang harus dipergunakan akan lebih tinggi lagi mengingat pengaruh farmakokinetik dan farmodinamik seperti daya absorpsi oleh usus, distribusi ke seluruh tubuh melalui sirkulasi darah, serta proses biokimiawi ataupun fisiologi dalam sel.

Pengaruh dari pemberian propolis pada sel makrofag timbul karena interaksi molekul yang terkandung pada propolis yaitu flavonoid dengan reseptor pada sel. Flavonoid diketahui dapat memperbaiki proses biokimia dan farmakologis terhadap fungsi sistem imun dan juga sel yang berperan dalam proses inflamasi seperti sel $\mathrm{T}$, sel B, makrofag, neutrofil, sel mast, dan basofil. Beberapa jenis flavonoid memiliki kemampuan memengaruhi kerja enzim dalam proses terjadi inflamasi. Enzim tersebut berperan dalam sinyal transduksi dan mengaktifkan proses proliferasi sel T, aktivasi sel B, atau memproduksi sitokin yang menstimulasi monosit. ${ }^{18}$

Penelitian yang telah dilakukan sebelumnya mengungkapkan propolis secara in vivo yang dapat meningkatkan ekspresi gen TLR-2 dan TLR$4 .{ }^{11}$ Telah diketahui bahwa gen TLR-4 merupakan reseptor pada sel fagosit yang mampu mengenali keberadaan lipopolisakarida (LPS) yang ada pada dinding sel bakteri gram negatif, salah satunya yaitu EPEC. Pada penelitian ini, peningkatan kemampuan aktivitas fagositosis pada kultur makrofag yang diberi ekstrak etanol propolis dapat disebabkan oleh peningkatan eskpresi gen $T L R-4$. Sinyal transduksi TLR-4 dimulai dengan terikatnya LPS oleh LPS-binding protein (LBP). LPS yang telah terikat oleh LBP kemudian akan berikatan dengan cluster of differentiation 14 (CD14). Kompleks LPS-CD14 kemudian akan diikat oleh TLR-4 melalui MD2 (modulation2). MD2 diperlukan guna menginduksi sinyal pada TLR4. Sinyal TLR-4 dapat mengaktifkan jalur My88 (myeloid differentiation primary response gene 88) dependen dan MyD88-independen. Aktivasi ini kemudian akan mengaktivasi nuclear factor kappa-B (NF-Kb) yang memediasi aktivitas proinflamasi sitokin interleukin-1 (IL-1) dan gen interferon tipe I. ${ }^{11,19}$

Fagositosis antibodi oleh makrofag yaitu awal respons imun innate. Antigen yang difagosit oleh makrofag akan dipecah menjadi antibodi yang bersatu dengan vesikel yang mengandung protein major histocompatibility complex-II (MHC-II) dan akan mempresentasikannya ke sel T $\mathrm{CD}^{+}$. Sel T memodulasi fungsi sel B melalui sejumlah cara. Sitokin asal sel T yaitu IL-4, IL-5, IL-6, IL2 , dan IFN (interferon) meningkatkan proliferasi sel B dan diferensiasi menjadi sel plasma yang memproduksi antibodi. ${ }^{9}$ Peningkatan aktivitas maupun kapasitas fagositosis diharapkan dapat berpengaruh pula pula peningkatan respons imun adaptif.

Berdasarkan penelitian dapat disimpulkan bahwa propolis mampu meningkatkan aktivitas maupun kapasitas fagositosis sel makrofag terhadap bakteri EPEC dengan konsentrasi minimal ekstrak etanol propolis.

\section{Daftar Pustaka}

1. Departemen Kesehatan Republik Indonesia. Pemberian terapi imunomodulator herbal: Health Technology Assesment. HTA. 2004: $1-40$.

2. Lofty M. Biological activity of bee propolis in health and disease. Asian Pac J Cancer Prev. 2006;7(1):22-31.

3. Jose MS, Vassya B. Propolis: is there a potential for the development of new drugs? J Ethnopharmacol. 2011;133(2):253-60.

4. John WE Jr, Douglas B, Lenore A, Gary B, Johanna TD, Folts J, dkk. Flavonoids and heart health. J Nutr. 2007;137(3):718S-37.

5. Koca U. Elevation of the flavonoid content in grapefruit by introducing chalcone isomerase gene via biotechnological methods. Turk J Pharm Sci. 2007;4(3)115-24.

6. Comalada M, Ballester I, Bailón E, Sierra S, Xaus J, Gálvez J, dkk. Inhibition of proinflammatory markers in primary bone marrow-derived mouse macrophages by naturally occurring flavonoids: analysis of the structure-activity relationship. Biochem Pharmacol. 2006;72(8):1010-21.

7. Wu J, Omene C, Karkoszka J, Bosland M, Eckard J, Klein CB, dkk. Caffeic acid phenethyl ester (CAPE), derived from a honeybee product propolis, exhibits a diversity of antitumor effects in preclinical models of human breast cancer. Cancer Lett. 2011;308(1):4353

8. Orsatti CL, Missima F, Pagliarone AC, Bachiega TF, Búfalo MC, Araújo JP Jr, dkk. Propolis immunomodulatory action in vivo on Tolllike receptors 2 and 4 expression and on proinflammatory cytokines production in mice. Phytotherapy Res. 2010;24(8):1141-6. 
9. Abul KA, Andrew HL. Cellular and molecular immunology. Edisi ke-5. Philadelphia: Elsevier-Saunders; 2005.

10. Matsumura N, Takeyama Y, Ueda T, Yasuda T, Shinzeki M, Sawa H, dkk. Decreased expression of toll-like receptor 2 and 4 on macrophages in experimental severe acute pancreatitis. Kobe J Med Sci. 2007;53(5): 219-27.

11. Sandor F, Latz E, Re F, Mandell L, Repik G, Golenbock DT, dkk. Importance of extra- and intracellular domainsof TLR1 and TLR2 in NFKB signaling. JCB. 2003;162(6):1099110.

12. Cleary J, Lai LC, Shaw RK, StraatmanIwanowska A, Donnenberg MS, Frankel G, Knutton S. Enteropathogenic Escherichia coli (EPEC) adhesion to intestinal epithelial cells: role of bundle-forming pili (BFP), EspA filaments and intimin. Microbiology. 2004;150(3):527-38.

13. Radiati LE, Awwaly KU, Kalsum U, Jaya F. Pengaruh pemberian ekstrak propolis terhadap sistem kekebalan seluler pada tikus putih (Rattus novergicus) strain wistar. J Teknologi Pertanian. 2008;9(1):1-9.

14. Linawati M, Bagiada M. Pengaruh propolis terhadap sekresi interleukin-12 pada supernatan kultur makrofag dari penderita tuberkulosis paru yang diinfeksi Mycobacterium tuberculosis. J Internal Med. 2009;10(1):1-10.

15. Donay JL, Fernandes $\mathrm{P}$, Lagrange $\mathrm{PH}$ Herrmann JL. Evaluation of the inoculation procedure using a $0.25 \mathrm{McFarland}$ standard for the BD Phoenix automated microbiology system. J Clin Microbiol. 2007;45(12):40889.

16. Chairul, Praptiwi, Marusin S. Phagocytosis effectivity test of phenylbutenoid compounds isolated from Bangle (Zingiber cassumunar Roxb.) Rhizome. Biodiversitas. 2009;10(1):40-3

17. Sofiyatin R, Sumarno, Widjajanto E. Sumbawa mares milk increase cellular immune respons of peritoneal macrophages of mice treated with Salmonella typhimurium. J Kedokteran Brawijaya. 2010;1(XXVI):14-9.

18. Garcl'a-Lafuente A, Villares A, Guillamo'n MA, Martı'nez JA. Flavonoids as antiinflammatory agents: implications in cancer and cardiovascular disease. Inflamm Res. 2009;58(9):537-52.

19. Lu Yc, Yeh WC, Ohashi PS. LPS/TLR4 signal transduction pathway. J Cytol. 2008; 42(2):145-51. 